\title{
Education reform sparks teacher protest in Mexico
}

Teachers from different parts of Mexico protest education reform in Mexico City on Sept. 4, 2013. Striking teachers are protesting after

Mexico's Senate overwhelmingly passed a sweeping reform of Mexico's public school system, banding President

Enrique Pena

Nieto an important victory in his push to remake some of his country's institutions. (AP Photo/Ivan Pierre Aguirre)

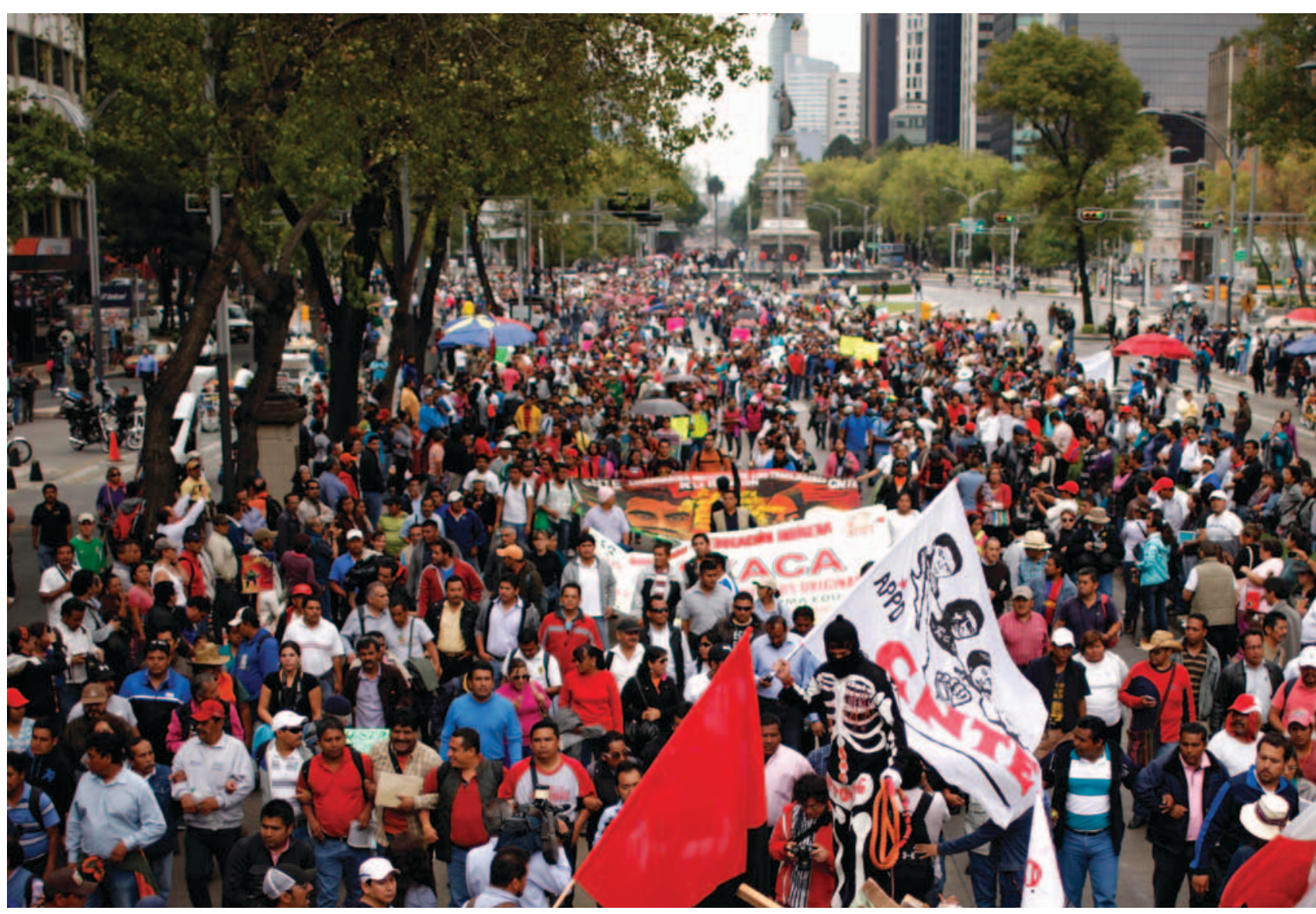

The tumult in Mexican education has deep roots in politics and tradition, but it is latter-day global competition and international measures of student performance that are driving reform efforts.

\section{By Bradley A. Levinson}

For nearly a year now, a shifting amalgam of protesting teachers has maintained a permanent encampment at the Monument to the Revolution near the center of Mexico City. What's more, since early September 2013 when the Mexican Congress approved sweeping new education reform, similar protests have erupted across many of Mexico's 31 states. By some estimates, as many as $50 \%$ of Mexico's public schools have remained closed for days or weeks at a time as teachers strike. Among other things, teachers have protested elements of the new reform law that link teacher employment and promotion to student performance on standardized tests.

BRADLEY A. LEVINSON (brlevins@indiana.edu) is professor of education in the Department of Education Leadership and Policy Studies and adjunct professor of anthropology and Latino studies at Indiana University, Bloomington, Ind. 
Teacher strikes and demonstrations are not new in Mexico. But issues raised by today's protesting teachers represent a combination of perennial grievances and new fears and concerns. The outcome of the conflict has potentially huge stakes for the direction and quality of basic education in Mexico.

"We are not opposed to assessment," says one common sign at teacher marches. "We are opposed to weakened labor laws masquerading as educational reform." Striking teachers also claim they have the best interests of Mexican children at heart. The way forward to higher quality education for Mexico's children, they say, is by supporting teachers' professional development, not punitive assessment.

\section{Roots of the conflict}

We cannot understand the deeper roots of today's conflict without accounting for the historical rise of the largest union in Latin America, the $\mathrm{Na}$ tional Union of Educational Workers (Sindicato Nacional de Trabajadores de la Educación, or SNTE), and the fractures and controversies the union has generated. The SNTE was founded in 1943 as part of a "ruling pact" of the dominant political party, which ultimately came to be called the Institutional Revolutionary Party (Partido Revolucionario Institucional, or PRI). A classic example of what political scientists call a "corporatist state," the PRI ruled by formally incorporating large federations of professionals, industrial workers, and small farmers, and giving them limited largesse and perks in exchange for exercising control and party discipline. Despite regular, constitutionally required elections, the PRI controlled federal power - and most state governorships - until 2000, and the SNTE remained one of its staunchest supporters.

The SNTE was well-positioned to capture most new teaching positions created by the dramatic, oildriven expansion of public education in Mexico, which by the mid-1980s had achieved near-universal coverage and gender parity for primary age students. Borne of the ruins of the 1910-1920 Revolution, schools had become a point of nationalist pride. Teaching became a relatively well-compensated and prestigious occupation and an important route of socioeconomic mobility for the children of peasants and workers. Before 1984, when new regulations required the equivalent of a bachelor's degree (licenciatura), teachers of primary and even lower secondary (grades 7-9) schools only needed teacher training for four years beyond lower secondary.

The SNTE had almost exclusive control over the teaching profession - indeed, over all school workers, including supervisors, secretaries, and janitors. New workers were automatically enrolled in the SNTE and the federal government transferred a portion of all teacher salaries to the SNTE in the form of involuntary dues. Union loyalty from this time forward also resulted in a long-standing practice - an open secret, really - whereby SNTE members upon retirement commonly sell or bequeath their positions to friends and family.

By the 1980s, just as Mexicans from all walks of life began to clamor for greater democracy and higher education quality - rather than just quantity or coverage - the country entered a prolonged period of economic crisis. Teacher salaries stagnated and didn't keep up with inflation; student enrollments began to flatten. The PRI initiated structural reforms to expand markets and shrink the role of the state. In this context, the ruling group of the SNTE elected as its president the fast rising, mercurial leader of a Mexico City union section, Elba Esther Gordillo. Eventually declaring herself the "leader for life" of the SNTE, Gordillo maintained a tense and conditional alliance with the PRI by appeasing her base with satisfactory gains in salary and working conditions while continuing to procure key positions in the education ministry for loyal SNTE cadres.

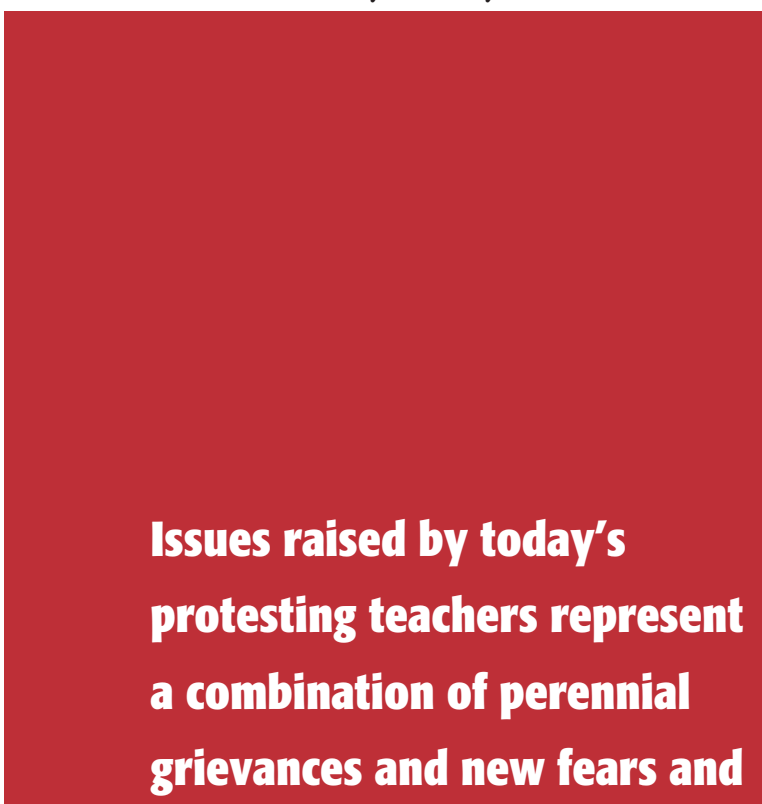

\section{concerns.}




\section{"We are opposed to weakened labor laws masquerading as educational reform."}

Rejecting calls for a more democratic and transparent union, Gordillo's astute machinations made her a kingpin of Mexican politics.

\section{CNTE rises; SNTE shifts its politics}

The primary dissident group that emerged to challenge the SNTE leadership's power was the Coordinadora Nacional de Trabajadores de la Educación (CNTE). Agitating for greater grassroots teacher participation, both within the union and the school system, the CNTE has controlled union sections in Mexico City and a few states, but it hasn't been able to break Gordillo's power at the national level. Meanwhile, Gordillo and the SNTE leadership changed course and eventually supported the rightist PAN political party, whose presidential candidate beat the ruling party candidate in 2000 to break 71 years of single-party rule in Mexico. As a consequence, the SNTE was forced into concessions of the PAN party's "modernization" agenda. This agenda included more emphasis on standardized testing in teacher pay and promotion, and merit-based examinations for new teaching positions.

The end of 2012 saw a return of the PRI to the Presidency in the figure of Enrique Peña Nieto. Peña Nieto reasserted federal control over education and, ostensibly, broke the power of the SNTE by jailing Gordillo on corruption charges (though Gordillo loyalists still retain nominal control of the SNTE). $\mathrm{He}$ also crafted a political "Pact for Mexico" with support from all three major parties. Among the more important educational changes to comprise the Pact were consolidating and granting complete autonomy to the National Institute of Educational Assessment (INEE) and, most controversially, creating a new General Law for a Professional Teach- ing Service. The latter assigned new teaching and administrative positions according to examination results and other meritocratic criteria, eliminating the discretionary power of SNTE leadership to make such assignments based strictly on "prior possession" of positions, seniority, or loyalty. Teachers' pay, job security, and promotion are also linked to students' exam performances. In a remarkable display of political unity and alacrity, by September 2013, scarcely 10 months after Peña Nieto took office, both chambers of Congress and a plurality of state congresses had ratified all of these changes.

\section{PISA and the OECD}

Why did such drastic education reform come to be seen as essential? There is plenty of anecdotal evidence and disturbing trends in Mexico's national examinations and school repetition rates showing that only meager progress has been made in Mexican children's basic skills despite 20 years of various education reforms. Yet what seems to have carried the most weight in public opinion has been Mexico's disappointing performance on international exams, especially the Program for International Student Assessment (PISA), which is an initiative of the Organization for Economic Cooperation and Development (OECD). As Mexico has strived to attain "first world" development status, the PISA exams have showed how clearly the nation's educational attainment lags. In triennial mathematics, science, and reading exams from 2003 to 2009 , Mexico typically placed below Turkey and Thailand and just above Brazil, with little improvement across the years. Particularly disconcerting was the percentage of students placing at or below the lowest level of competency for mathematics $(55 \%-65 \%$ vs. the OECD 
average of $20 \%$ ), and at or above the highest level of competency ( $0.4 \%$ vs. the OECD average of $12 \%)$. Media typically have portrayed these PISA results as a source of national shame, and have pointed out that Mexico's education expenditure compares favorably to countries with much higher levels of achievement. (The most recent 2012 PISA released in December, 2013 - after Mexico's education reform laws had passed - show more consistent, albeit still quite modest improvement.)

\section{Contrast of the conflict}

According to many, what is at stake in the current conflict is nothing less than the vision and direction of public education in Mexico - with the status, professional autonomy, and economic security of teachers at its heart. On one side of the conflict are reformers, who want to uproot old patterns of corruption and favoritism thought to have held back educational advancement, and reassert federal control. They have scaled back long-standing labor rights and tied educational quality to accountability and assessment. In so doing, they have embraced the logic of assessment favored by the business class and the OECD. (It is no coincidence that the proposed Mexican assessment regime bears a striking resemblance to the high-stakes testing inaugurated by No Child Left Behind in the United States. These are truly global trends.)

The kinds of "competencies" purportedly measured by such assessments seem to be determined, above all, by a curriculum increasingly oriented to the demands and requirements of a competitive global economy and labor market. Yet even some of those skeptical of the technocratic orientation of the new reforms suggest they're necessary and long overdue. Prominent educational sociologist and longtime SNTE critic Carlos Ornelas argues for giving the new reforms a chance. He is cautiously optimistic about the quality and justice that a new meritocracy could foster. "The hope is that the reforms will consolidate a new democratic centralism that permits the government to regain legitimate authority and discipline," he said.

On the other side stands a much-maligned teaching corps that has scarcely been consulted about the reforms. The teachers and those who defend them say that they represent a rich educational tradition rooted in scientific humanism and national secular values, and that they also have the savvy and wherewithal to contribute meaningfully to educational reform if they are respected and supported. Such teachers carry an important stock of professional knowledge, and they also often forge deep relationships of mutual support and respect in communities where they work. Now, suddenly, they face punitive measures for failing to raise academic achievement to a level determined mainly by foreign and business interests. Teacher advocates question the meaning of "quality" advanced by reformers and defend a model of education they say generally has served Mexico's children well. They want meaningful education reform that supports teachers' professional development and holds them reasonably accountable for educational achievement but that also makes assessment more formative than punitive and takes account of students' socioeconomic profile. (By early 2014, teacher protests had arguably achieved some success in this regard; the INEE was insisting that the performance exams under development would be "formative" and would include qualitative and observational assessments alongside quantitative measures.) They also want to continue educating children for social solidarity as much as for the market, and to retain their constitutionally protected labor rights.

\section{Mexican teachers face punitive measures for failing to raise academic achievement to a level determined mainly by foreign and business interests.}

\section{Reform unites old foes}

Most telling about teacher protests and strikes in the last year is that they no longer correspond mainly to CNTE membership. Protests that over the past 25 years had been overwhelmingly concentrated in Mexico City and a few states where the CNTE holds power have now become far more generalized to other states that are likely to be former bastions of SNTE power. Teachers allied with the SNTE have taken up common cause with the CNTE. Are these just teachers trying to hold on to antiquated perks like the selling of teaching posts, or do they represent something far more principled? I posed a version of this question to Rodolfo Ramírez, longtime editor of the popular educational magazine Cero en Conducta. "The huge extent of the discord can be explained as a combination of factors: teachers' fear over assessment 'with consequences' (as the Secretary of Education proudly calls it), and over the fairness and rigor of that assessment, but also, frankly, the defense of corrupt rules and arrangements. Only a detailed investigation would reveal which of these factors carries the most weight," he said.

In the meantime, the battle for the hearts and minds of Mexico's public will continue to play itself out in the streets and schools. 